\title{
DE LITORE DELETO: \\ DEFENSA DE LOS ESPACIOS LITORALES FRENTE A LAS AGRESIONES URBANISTICAS
}

\author{
Manuel María Zorrilla Ruiz \\ Catedrático Emérito de la Universidad de Deusto \\ Ex-Presidente del Tribunal Superior de Justicia del País Vasco
}

A la memoria de Antonio Marzal Fuentes, ejemplo, para todos, de amor a la verdad e inolvidable amigo

\section{Fenómeno irruptor del urbanismo salvaje en los espacios litorales}

La injerencia del hecho marítimo - que abrió la era de los descubrimientos- en las operaciones comerciales de entonces, explica lo incipiente de una mundialización que inspiraba el dogma de la libertad de los mares y esbozaba los principios de un Derecho de Gentes previo a las construcciones del moderno Derecho Internacional Público. Los actuales capítulos de la mundialización - concepto indeterminado y expansivo que subyace a situaciones proteicas - incluyen un hecho marítimo que no es fruto de la movilidad de los experimentos comerciales, sino de los desplazamientos de las personas y grupos que - cautivados por las atracciones turísticas, los mimetismos de la época y los alicientes del mercado- se acomodan en los espacios litorales invadidos por la concupiscencia del urbanismo salvaje.

La perspectiva - obligada en la era mundializadora - de un Derecho de Gentes arreglado a ese estado de cosas, descubre las orientaciones que, andando el tiempo, arraigan en el discurso politicolegislativo y, a causa de su madurez, facilitan la concreción jurídica de los supuestos regulares o anómalos del urbanismo litoral. Así se aúnan las orientaciones adecuadas al dictado de la recta razón - que se invoca clamorosamente- e incompatibles con las desventuras medioambientales y/o geográficas en que se localizan los bienes deseados y los males de que se abomina.

Dichos juicios constan de prevenciones prudentes que, sin afán exhaustivo, persiguen objetivos certeros. Hay que atender a la condición física y jurídica de los bienes y derechos lastrados por irrupciones varias. Unas, las de quienes, ejercitando su libertad de movimiento y 
aprovechando las oportunidades del derecho al ocio, gozan de la habitabilidad de las zonas costeras. Otras, las de los individuos o entidades que - entregados profesionalmente a operaciones de edificación inmobiliaria- controlan el ritmos de esos flujos. Otras, las de los sucesos naturales que, conexos con tales fenómenos, atraen consecuencias que escapan a las más escrupulosas previsiones.

El dogma de planificación urbanística descansa en la idea -emanada de una sensata iniciativa, coherente con los afanes de firmeza social y respetuosa con la naturaleza de las cosas- de que la apuesta racionalizadora de la geografía litoral cumple dos funciones. Completa, de una parte, la espontaneidad de las acciones enderezadas a la prosperidad del urbanismo que allí se desarrolla. Repara, de otra, en las flaquezas de la condición humana y tiende a corregir los desvaríos de una seudocreatividad desconcertante o esperpéntica.

Los componentes del proceso que así evoluciona, se clasifican en factores dominables y factores de difícil control. Surgen éstos en los ciclos de urbanización que, desdeñando las funciones sociales de la propiedad privada, abusan del derecho - fundamental tras la europeización comunitaria- a la libertad de empresa en el marco de una economía de mercado. Cuando ambos derechos - connaturalmente limitados- no se armonizan tempestivamente y acusan lo inviable de su coexistencia, los poderes públicos han de obrar con la diligencia precisa para liquidar cuantas disfunciones sociales rebajan la igualdad y la libertad materiales de las víctimas de esos desafueros. La efectividad y solvencia -algo más y distinto de la eficacia simple - de la planificación, predicen un orden futuro que, para acondicionar la habitabilidad de las zonas costeras, elimine las disfunciones que aquejan a la buena marcha del mercado, mitigue las ansias de especulación económica y dé curso a los elementos - técnicos y jurídicos- que hacen falta para que, sin desertar de su vida en dignidad, la persona humana reafirme los hábitos de su cosmoeminencia.

Los espacios litorales soportan - desde que se encendieron las señales febriles de su explotación productiva - las secuelas de una expansión que, revestida de los rasgos del urbanismo salvaje, paraliza las tentativas de controlar los procesos de crecimiento inmobiliario que registran. Esta contrafigura de la estética ofrece caracteres que, unas veces, coinciden con los estímulos que causan el abuso y, otras, derivan de las perversiones a que el abuso da lugar. Las novedades del derecho al ocio - cuyo contenido esencial o núcleo invulnerable pende de una definición esmerada - producen reacciones inertes que no se deben a la autonomía de sus titulares, sino a los desafíos -irreflexivos y egoístas - de un mercado que emite sus ofertas sin un ápice de sensibilidad. Otro tanto cabe decir de los móviles que, para conjurar estos riesgos, 
inspiran el ejercicio de los derechos concurrentes, cuyas bondades se falsifican o se esfuman. Se llega a sostener —en virtud de quién sabe qué sugestiones latentes o engaños- que la excelencia de la calidad de vida ha de ceder, no obstante sus halagos platónicos, en pro de los intereses inferiores que defienden los argumentos del consumismo a ultranza. Sin olvidar las ambigüedades de las Administraciones Públicas - situadas entre la espada del inventario de los hechos consumados y la pared de los deberes de su pleno sometimiento a la ley y al Derecho- y la carga de especulación económica que, para activar los procesos, anima el ejercicio de las correspondientes libertades.

\section{Hecho territorial de la protección urbanística de las zonas costeras}

El hecho territorial —requisito de la existencia del Estado y subyacente a su constancia - significa que la base física o establecimiento indispensable para ejercitar la soberanía estatal, obedece a vicisitudes dependientes del emplazamiento de las zonas en que se localiza. Una de ellas conviene a las peripecias urbanísticas que - adheridas al signo de los tiempos - constituyen realidades ligadas al pluralismo de la vida social. El asalto urbanístico — que ha infligido un severo castigo a los espacios litorales - responde, más economicista que ecológicamente, al impacto de un torrencial flujo turístico. Hay una relación axiomática de continuidad entre el despliegue de estos movimientos y la celeridad de los reflejos con que, ante su aparición, reaccionan los agentes del urbanismo salvaje. La seducción colectiva de los derechos al encanto del ocio, al entretenimiento que enriquece y a la solidaria utilización del medio ambiente, explican el apresuramiento y los afanes, así como también el caos y la lesividad de ese incremento panorámico. Se denuncia el atentado contra un interés general que encuentra impensados obstáculos y que, vistas las dimensiones del ataque sufrido, no halla los medios aptos para contenerlo y fijar un mínimo de racionalidad. El modo que este urbanismo tiene de irrumpir en las zonas costeras, no facilita el examen sereno de su productividad social, ni de su vinculación al bien común en que radican los intereses generales. Ha cundido el convencimiento de que, al abordarse la generalidad del fenómeno, la actitud tibia y aún amnésica - lo contrario de comprometida y vigilante- de los poderes públicos neutraliza la entereza de un decisionismo oficial inhibido frente a los intereses - de determinación confusa y costosa- que enervan las aspiraciones sociales, residentes en la opinión pública, de transparencia informativa. 
El espacio litoral del territorio constituye - supuesto el haz de competencias ejercitadas sobre el mismo y su individualización como objeto de derechos subjetivos y situaciones jurídicas - un bien cuya importancia urbanística lleva a preguntarse por la necesidad de pautas que, sin desmesuras dogmáticas, adquieren la persuasión que se predica, en general, del discurso de las ciencias del espíritu y, en especial, de sus premisas politicolegislativas. Amén del razonamiento, más circunstanciado y modesto, de la técnica jurídica que entra al servicio de su aplicación. Estos principios cautivan el entendimiento, que los asimila porque están en la naturalera de las cosas y en el dato de ser preferibles a fórmulas alternativas que, sin alejarse de lo razonable, le son conceptualmente inferiores. Se comprende la solidez que les asiste y, tras la comprobación de sus bondades, prevalece a causa del acierto que en su elección concurre. Si satisfacen la percepción intelectual, es porque su metodología selectiva y la positividad de sus efectos descartan opciones diferentes. Su calidad antropocéntrica - a la vista de las constantes y variables que en su adopción confluyen- esboza un panorama del que se aleja lo veleidoso y/o aberrante. Los mensajes que entonces se construyen, son proposiciones jurídicas indeterminadas que, a imagen y semejanza de los conceptos así denominados, disuaden de aventurismos, sin pies ni cabeza, o de improvisaciones arbitristas que a nada conducen.

Los elementos intelectualistas se completan con el realismo de la razonabilidad y la cordura, concretando los accidentes de las situaciones que animan los principios o sobre las cuales operan sus líneas de fuerza.

Se atiende, en primer término, a la cantidad de las acciones registradas en el ámbito de las zonas costeras, pues el interés general -anejo a ellas- depende de su frecuencia, habitualidad y probabilidades de multiplicación. Dato metodológicamente indispensable para que los principios se destilen con integridad y no estimulen la falsificación de sus identidades. Debe también estarse al accidente de la cualidad, porque una selección indelicada de los hechos ingiere vicios de heterogeneidad que empañan la validez del discurso. No menos, hay que sopesar la interrelación de lo cuantitativo y lo cualitativo en la realidad litoral analizada, porque, si no se separa la paja del trigo, la metodología empleada se resiente de algunas inexactitudes. Puesto que se actúa sobre realidades sociales - como las consistentes en las migraciones, internas o transfronterizas, que engendran el fenómeno del urbanismo litoral- y no cabe eludir sus relaciones, hay que apreciar su dinamismo o fuerza de irrupción y trasladar a los principios un referente que le justifique. Deben constar los ingredientes activos que ayudan a deducir 
los principios buscados, acogiéndolos en la medida justa para no adulterar su naturaleza ni menguar el alcance de la función orientadora y/o normativa que se les otorga. No puede omitirse la constancia de las servidumbres o limitaciones que restringen la visibilidad y restan facilidades a la obra de su definición. Estándose a las circunstancias del tiempo y del lugar, se acreditan los cambios - relevantes y no indiferentes- que influyen en la formulación de los principios. Es obligado, en fin, determinar - como expresión de la voluntad de la naturaleza- la medida en que el fenómeno se debe a comportamientos espontáneos, a incentivos de movilización intencionada o a inertes consecuencias que se suceden en cascada.

La expulsión del urbanismo salvaje de las zonas costeras, no es trabajo sencillo, como lo acredita el que todos —agentes de carácter público, personas y grupos comprometidos en la empresa, y portadores de intereses conexos o difusos- compiten en la tarea de inventariar sus inconvenientes, para que, auxiliados de aquellos principios, los aborden con criterios de inquietud intelectual y actitud sorprendida, pero siempre resuelta a despejarlos, es decir, agotando los alicientes de la curiosidad y las reacciones del asombro. Lo primero, porque el relieve social de las agresiones urbanísticas en los espacios litorales, aviva sextos sentidos e intuiciones que causan pavor y/o desconcierto. Lo segundo, porque impresionan lo grandioso de la puesta en escena de esas adquisiciones y la capacidad que, para despertar optimismos o desilusiones, significa a los retos que les acompañan.

La defensa de los espacios litorales frente al urbanismo salvaje —necesitado de esas contribuciones- se completa con ejercicios de paciencia y minuciosidad. No puede bajarse la guardia si, pese a la razón que asiste, abundan las victorias que otras fuerzas -incorporadas a las desaprensivas filas de los poderes de hecho- consuman impunemente y con daño para la causa del Derecho. Sin omitir la tenacidad indispensable para olvidar de inmediato esas derrotas y continuar en pos de soluciones - jurídicas y técnicas- que acaben venciendo a tan obstinado adversario.

\section{Particularidades de la zona marítimo-terrestre}

La zona marítimo-terrestre se separa de la tierra firme por el trazo — evasivo y polémico- que ha dado en llamarse ribera del mar. Los pormenores de su concreción física difieren de los procesos individualizadores de los cuerpos ciertos —en que la nota de movilidad no es esencial - y la exactitud de su concepto rechaza, para definirla, otros 
criterios simplificadores. Dicha zona comprende la franja litoral del dominio público por naturaleza, que, según el discurso y la nominación intelectualistas, cumple las condiciones -intuitiva e instintivamente admitidas - que de antiguo le adjudican esa calificación. También se extiende - pues ahí reside su singularidad- a superficies y espacios que, ajenos a la determinación conceptual del dominio público, se le asimilan en circunstancias de excepción que, con el tiempo, llevan traza de convertirse en duraderas.

De ahí, las sugerencias que invitan a rehabilitar dogmáticamente una figura - la de la zona marítimo-terrestre- cuya fisonomía no hace de su redefinición un lujo estéril y sirve a una insistente demanda social, superando los inconvenientes de las definiciones obsoletas e inaplicables de presente. La especificación de la zona marítimo-terrestre requiere precisar los componentes típicos de su perfil geográfico, pues no es fácil hacer una síntesis de sus elementos y comprender la integridad de su significado.

Un reparo de primera línea consiste en la deformación que ha sufrido la idea de la zona marítimo-terrestre, pues no ha parecido heterodoxo - antes bien, resignadamente admisible - admitir que englobe superficies de propiedad particular. Proposición reñida con la indisponibilidad que apareja la extracomercialidad de los bienes de dominio público, con su inmunidad a los efectos del modo de adquirir la propiedad por prescripción, y con su sustracción a las transformaciones -físicas y jurídicas- de la ejecución forzosa.

Las oleadas del urbanismo salvaje —que, al ocupar los espacios litorales, aniquilan sus activos estéticos y liquidan formas de vida ya consolidadas - constituyen focos de agresión que disuelven los rasgos a que se apelaba para estabilizar la naturaleza jurídica de la zona marítimo-terrestre. Una sucesión de operaciones jurídicas adjudicó a esos espacios la nota de alienabilidad. Comenzó disponiéndose de los derechos subjetivos sobre el suelo y el vuelo que se individualizaban. El régimen de las autorizaciones administrativas canceló los obstáculos que impedían atribuir a los nuevos y bienaventurados poseedores las facultades de uso y disfrute que se les asignaban. Los actos de individualización produjeron efectos sorprendentes, al aflorar superficies excedentes que, desglosadas del dominio público, mudaban de naturaleza y devenían bienes patrimoniales. La posibilidad de enajenarlas - tras las modificaciones ocurridas- agotaba un ciclo de privatización minuciosamente diseñado. El dominio público se desvanecía con la asignación de parcelas que, sin transmitir la posesión en concepto de dueño, se invadían mediante concesiones administrativas que -otorgando el uso especial y privativo de los excedentes- minimizaba las prerrogativas pú- 
blicas. Tendencia contenida, en parte, gracias a las servidumbres de vigilancia litoral, paso y salvamento, que — paliando los desgastes y malos ejemplos de las anomalías del dominio público- protegen el uso público de una zona marítimo-terrestre, achicada por la sustracción de los espacios que se arrebatan a su naturaleza.

La osadía de las invasiones litorales por el urbanismo salvaje, frenó la aplicación de los principios que - encarando, con acierto, los problemas del caso- inspiraban disposiciones y actos acordes con la naturaleza de las cosas y las directrices del Derecho objetivo. Las soluciones planificadoras asumieron un papel arrollador que, además de erosionar las medidas oficiales de racionalización y canonizar los hechos consumados, despreciaron las exigencias básicas del uso público de la zona marítimoterrestre. Por si ello fuera poco, los automatismos del mercado de libre competencia abrieron un ciclo enloquecido, dentro del que los terrenos edificables y los espacios más cercanos al mar soportaron una demanda paroxística que la antisocialidad de la irrupción elevó a dogma de fe y a presupuesto de sus avideces económicas.

La corrección jurídica de las anomalías advertidas en la zona marítimo-terrestre depende de aplicar, sin concesiones a una equidad que no lo es, los principios idóneos para liquidarlas. Hay que reformular, con precisión terminológica, ciertas proposiciones del ordenamiento jurídico, cuya lectura frágil fomenta las costumbres hostiles a la legalidad y santifica reparos insalvables. La tendencia a trivializar - cuando, no en vano,... en principio era el verbo...- el peso específico de las palabras o juicios de las normas jurídicas atentas a esos pormenores, favorece - so pretexto de la simplificación de las formas y la celeridad de los efectos- la elusión o, lo que es más grave, la malversación de los mandatos y/o prohibiciones pasados por alto. Circulan, para colmo de males, interpretaciones económicas del Derecho — tan precipitadas como codiciosas - que maltratan el tino de las operaciones correctoras.

Otra es la constancia de que el urbanismo salvaje se adueña de superficies litorales cuyo tratamiento resulta incompleto — ante la apresurada consunción de sus iniciativas - y exento de una cosmovisión —que nadie cuida de sugerir y, aún menos, de emprender- sobre los trances de experiencias urbanísticas que, iniciadas o en vías de progreso, son estadísticamente provechosas para las inducciones previas a la obtención de los principios. La tutela de las comunidades asentadas en los espacios litorales explica las restricciones pensadas para reprimir —con pausada energía que raya en laxitud - las variantes de la agresión urbanística, en general $\mathrm{y}$, en especial, las corrientes monoturísticas con que se interaccionan. Lo cual descansa en postulados inherentes a la cosmoeminencia y dignidad de la persona humana que sufre el daño de esas convulsiones. 
Se echan en falta ayudas que decisivamente apoyen el buen fin de las operaciones racionalizadoras. Es llamativo que, pese a la importancia de los temas, se margine con deleite insensato un principio central para garantizar la aplicación de los demás que se le asocian. Principio que atañe a una gestión reflexiva, ininterrumpida y acertada. Si se prescinde de ella, se desmoronan las expectativas y oportunidades de las instancias llamadas a coordinar eficazmente sus intervenciones. A saber, las que asumen la función defensiva de los espacios litorales, las encargadas de preservar su identidad, las que reordenan la afluencia de las corrientes migratorias, y las que, ejercitando sus libertades económicas, mejoran las condiciones del espacio habitable y aportan componentes de calidad de vida.

Urge deshacer la confusión de la noción de litoral, a que se atiene el Derecho objetivo, con la definición del ámbito de dominio público que abarca la zona marítimo-terrestre. Bien entendido que la inquietud de la dogmática jurídica y los aleccionamientos judiciales reajustarán, probablemente, esas holguras.

\section{Tratamiento medioambiental de la dignidad personal y de la calidad de vida}

El medio ambiente es un entorno que el ser humano necesita para alcanzar, en la parte que le toca, el desarrollo pleno de su dignidad. No se trata de un hallazgo reciente, ni de un motivo más de curiosidad o de atracción, sino de proteger la esencia del ser personal frente a las agresiones urbanísticas que, proliferando en los espacios litorales, lesionan los intereses legítimos de los individuos y grupos arraigados en ellos. Las funciones que ha de cumplir el medio ambiente - afectado por esas invasiones - se alimentan de pautas que, a causa de lo impulsivo del fenómeno, se infringen con frecuencia. La primacía del medio ambiente, en ese punto, exige que, con el peso de un dogma de fe, prevalezca la idea de que la persona sólo vive cuando se redime como ser existente y duradero.

La salvaguarda de la salud básica - consistente en la ausencia de mal o menoscabo análogo- constituye un valor de que la persona es consciente y cuya privación -en cuanto pérdida de un bien debido al sujeto - procede de agresiones que, como los excesos urbanísticos, la deterioran o destruyen. Es axiomática la idea de que la salud elemental - acogida a los cuidados y la calidad del medio ambiente - no admite grados intermedios entre el todo o la nada. O se cuenta con la integridad de la salud básica, sin reducción ni menoscabo, o se está privado, de raíz, del bien en que consiste. 
El medio ambiente incluye la garantía de la reserva de salud o serie de adquisiciones sicofísicas que, además de resistir los asedios del urbanismo salvaje, combaten la intensidad con que erosiona las fuerzas de la voluntad, aumenta el desaliento y agrava el sentimiento de desilusión. La escasez de reserva de salud está en razón inversa de las compensaciones que el medio ambiente debe ofrecer a la persona.

El concepto polivalente y positivo de salud — que el medio ambiente escuda - se perfecciona gracias a la autorrealización o ausencia de tensiones que entorpecen la libertad de decisión con que el entendimiento y la voluntad se aplican al reparto justo de sus energías.

La protección del medio ambiente - que sirve a la naturalidad urbanística de las zonas litorales- comulga con la idea de que la persona posee una naturaleza biológica que le es propia, y constituye parte del acervo común de la familia humana. Sí, desgastada por las agresiones venidas de fuera, la naturaleza — de la que cuida el medio ambientedecae y se empobrece, la persona sucumbe a las contradicciones que la sojuzgan e impiden encajar la adversidad de su derrota.

El medio ambiente bueno para conjurar los peligros del urbanismo salvaje, acoge un componente previsor que mide el riesgo de esos atentados en función de su notoriedad, de su frecuencia y de la censura, más áspera que tenue, causada por su temibilidad. Posición que comparten cuantos se acercan al umbral de las situaciones jurídicas que van a afectarles y adoptan la determinación de resistir frente a lo inminente del asedio. La noticia fiable de estas situaciones en las zonas costeras, da un paso adelante y fortifica la voluntad de abordarlas, aunque aún no se cuente con los medios óptimos para hacerles frente. El recrudecimiento de esa información - transformado en conciencia crítica de un estado de cosas alarmante- convence de que, pese a la jactancia de la historia doméstica de sus éxitos, el urbanismo salvaje litoral no es un enemigo invencible. El discurso desemboca en una decisión moraliza$d a$ y dotada de los auxilios técnicos que provocan la beligerancia de un ordenamiento jurídico cuyas normas requieren su inaplazable aplicación. La promoción del medio ambiente no sólo se concibe para incentivar — con la sensibilidad de sus propuestas- el elogio de sus innovaciones y el servicio a la causa de los intereses generales, sino también para que sus contenidos útiles impregnen el curso de la vida individual y colectiva con el enriquecimiento — estético y vital— que se sigue de sus adelantos.

Las acciones de defensa que, desde frentes portadores de intereses muy varios, se oponen a los abusos del urbanismo salvaje en las zonas costeras, valoran lo brutal del arrojo con que esas situaciones se emprenden y consuman. No pueden afrontarlas, si no cuentan con sufi- 
cientes dosis de energía y efectividad. De la sociedad atomizada y monista, canonizada por el Estado demoliberal, se ha pasado a una sociedad pluralista en la cual - para tomar iniciativas vertebradas en cuestiones tan graves - el individuo se incorpora a grupos de vastos compromisos. Los grupos ya existentes realizan sus tareas con la garantía que les depara la experiencia de sus intervenciones históricas. Los grupos de aparición continuada y perceptible se someten disciplinadamente al control estadístico de sus fracasos o sus éxitos. Los grupos más recientes, cuales los defensores del medio ambiente frente a las agresiones del urbanismo salvaje, tropiezan con problemas de constitución sorprendente, diagnóstico difícil y trabajosa solución. Su grandeza y servidumbre son obvias. Lo primero, porque asumen la definición de un complemento que la persona necesita para seguir viviendo en dignidad y perfeccionar su presencia en la ciudad secular. Lo segundo, porque enajenan lo mejor de sus ímpetus en pro de una causa que desencadena hostilidades muy poderosas y temibles.

La solidaridad colectiva revela la intercomunicación de los grupos en las acciones defensivas de los bienes jurídicos que les incumben. Si la solidaridad colectiva resulta indispensable para servir a esos propósitos, lo es más a la hora de tutelar el medio ambiente, porque, advirtiéndose su ser y su significado, el éxito esperado no es algo extrínseco al concepto que de la misma ha de formarse, sino que pertenece a su contenido esencial. La persona es ella y la suma de las circunstancias que, en la órbita de su crecimiento, se suceden. Su dignidad consta de la cosmoeminencia — capacidad de dominar las agresiones indebidas o injustas- $-\mathrm{y}$ las expectativas que auguran una vida en plenitud, arreglada a la moralidad y legitimidad de sus afanes. Esta reflexión muestra el énfasis que es obligado poner en la lucha contra las agresiones urbanísticas, previa la invocación de una consigna que, no por difundida y reiterada, deja de causar admiración. A saber, la de que el principio de irregresividad - tan interdisciplinar como notorio- se extiende a esas operaciones defensivas, ya que su afán de poner coto a dichos atentados es parte del plan que escenifica un capital aspecto del progreso en pro de la edificación de una humanidad más humana. La solidaridad de los grupos sociales brota de la decisión colectiva de proteger un interés sumergido en el ciclo de conservación del medio ambiente y adherido a la aspiración de bienestar que le caracteriza. De ahí, que corresponda a los poderes públicos — deudores de las obligaciones naturales del esfuerzo de transformación - ocuparse de sus finalidades y proveer a satisfacerlas sin tardanza.

La conservación del medio ambiente - por las vías que los textos fundamentales apuntan o el decisionismo político insinúa- requiere 
que su acondicionamiento en los espacios litorales se produzca bajo el signo de las adquisiciones que el Estado social y democrático de Derecho garantiza con criterios obstantes a cualquier forma de degradación o de retroceso. Quiere ello decir que — como en tantos dominios ocupados por las ambiciones reformistas del dogma «... siempre más nunca bastante...»- los peligros de ese urbanismo incontrolado sólo se neutralizan trayendo a capítulo, sin treguas ni vacilaciones, los remedios brindados por los principios informadores del ordenamiento jurídico, por sus prohibiciones y mandatos, y por las recomendaciones del buen sentido de la opinión pública.

Contra la virulencia del urbanismo salvaje se acude a las ventajas que aportan la mejora y regularización del medio ambiente, rehusando las tentativas reductoras de sus niveles de excelencia y vigilando la radicalidad de los intentos de su depredación. Los medios llevaderos a esos fines han puesto en pie un derecho colectivo de resistencia, cuya eficacia - frente a las agresiones temidas o incoadas- es función de la perseverancia con que se ejercite. Las dificultades de la resistencia dependen de lo intensivo de las acciones oficiales que ejecutan las consignas de carácter transformador y social. Su protección de los espacios litorales frente a las irrupciones urbanísticas hostiles al imperio del Derecho, comprende las medidas de control o vigilancia diligente - que han de adaptarse a las circunstancias de las personas, el tiempo y el espacio receptor de las peripecias migratorias - del desarrollo del fenómeno urbanístico, impidiendo la iniciación, prosecución o término de los hechos lesivos. Requiere evitar la duración indefinida de cuantas situaciones propician la penetración del urbanismo anárquico y multiplican los efectos de las omisiones que se aprecian. Añade soluciones de apoyo, promoviendo iniciativas a que se suman los poderes públicos, conmovidos por la mala conciencia de anteriores incumplimientos o aliados con la creatividad que les impulsa a dispensar ayudas sin las que la audaz iniciativa de los particulares poco puede o fracasa. Se trata de encauzar —en pro de la intangibilidad del medio ambiente y del enriquecimiento que aporta - la destreza de los grupos coparticipantes, de suerte que la integración de ambos esfuerzos reconstituya el verdadero rostro de un urbanismo aseado y saludable, rehabilitando los valores sociales, geográficos y humanos de los espacios litorales.

La calidad de vida -erosionada o hecha trizas por la amenaza del urbanismo salvaje en las zonas costeras- equivale a un bien jurídico cuya delicadeza exige articular un sistema de protección acorde con dicha excelencia. Debe mediar una intencionalidad oficial que, a juzgar por lo transparente de las motivaciones enunciadas, disipe la sospecha de refugiarse en la retórica que, demasiadas veces, ha sido su solitaria 
compañera de viaje. Revelará una voluntad política — diferenciada de las promesas de ocasión y de las predicciones a la larga- cuya solicitud no dé lugar a duda y pueda controlarse, si la opinión pública -ilustrada y comprometida en las tareas de censura - se siente defraudada. Se precisa de especies racionalizadoras que revelan - al precio del éxito de una elección certera- lo espinoso de armonizar los medios y los fines. Esas técnicas inciden de lleno en el acervo de recursos naturales - que son parte del medio ambiente protegido- con intensidad bastante para dejarle a salvo. De ahí, la sensibilidad de los elementos componentes y lo peculiar de su emplazamiento, como parte del medio ambiente, en el seno o en la periferia de los espacios litorales que, a cargo de los poderes públicos, se benefician de las medidas de control y de apoyo. El adiestramiento a que obligan, recomienda emplear dosis de atención y cuidado que exceden de las previsiones habituales - atentas al simplismo dominador de los problemas generales- y han de adecuarse, estudiando un estado de cosas cambiante y movedizo, a las irrepetibles circunstancias de tiempo y de lugar de sus vicisitudes.

Tales análisis se caracterizan por una escrupulosa inmediación o proximidad física, por una intervención familiarizada con el hecho urbanístico de las franjas litorales, por sus antecedentes, evolución, estado actual y otros pormenores que, aunque secundarios, son de tener en cuenta. Se señalan por el conocimiento exhaustivo de una realidad que no basta con apreciar superficialmente, porque su red de conexiones es compleja y extensa a la hora de abordar los problemas que engendra. Tiene que actuarse con celeridad y energía, pues la ocupación de las franjas costeras por las irrupciones del urbanismo salvaje se sucede - gracias a las complicidades y artimañas de un centón de recetas de antijuricidad urbanística - con rapidez y desmesura que los creadores del Derecho objetivo y sus aplicadores no llegan siempre a tiempo de paralizar.

Parece que, a primera vista, la tutela de los bienes jurídicos de advenimiento más tardío, como la calidad de vida y el medio ambiente, se contiene en las relaciones nacidas de los sectores civil y administrativo del ordenamiento jurídico, pero no llama la atención del legislador penal. Hay acciones inducidas por los particulares y los grupos sociales - que invocan las normas del ordenamiento- o acuerdos estatales de control y de apoyo que, en pro de la supervivencia de esos bienes, movilizan la energía transformadora de los poderes públicos. La idea politicolegislativa general pone a su cargo y al de los agentes sociales significativos, los medios para restaurar el equilibrio alterado y devolver a los bienes dañados el trato que el Derecho les ha conferido. Tiene que haber circunstancias muy cualificadas de peligro social, para que, am- 
pliándose el marco defensivo de esos bienes, intervenga el poder punitivo del Estado. Cuando el pluralismo social se expone a las desvertebraciones causadas por la evaporación de los valores de progreso positivo, cae de su peso la necesidad de llamar a las puertas del Derecho Penal para vigorizar - justificadamente y no en virtud de un voluntarismo caprichoso- los elementos de protección utilizables.

De ahí, la estima que merece la suerte reservada al medio ambiente y las versiones que su defensa ha registrado en las zonas costeras afligidas por los desafueros urbanísticos. Los aberrantes resultados de que el urbanismo salvaje alardea - atentando contra el núcleo de la vida social, confiscando, por actos de fuerza, sus adquisiciones más caras, despreciando la prevalencia de valores asentados con harto sacrificio, y cosificando la dignidad de la persona- exhuman el rostro cuasidemoníaco de un fenómeno ante el que los legisladores penales no pueden continuar impasibles. Sigue en pie - según lo razonado, hasta el momento, con carácter general o específico - la obligatoriedad de adoptar, sin margen para el libre albedrío de la legislación, modelos de injusto penal que, mediante sanciones coherentes con la culpabilidad personal y el tanto de alarma social que se produce, aseguren la protección del medio ambiente.

\section{Instalación y arraigo litorales de los movimientos migratorios}

El dato demográfico de la instalación — acelerada y masiva- en los espacios litorales precedió a las animaciones del espectáculo invasor del urbanismo salvaje. Las migraciones se debieron a usanzas dependientes de una promoción ideada por los modelos de Política Social que innovaban consignas de bienestar y de prosperidad. Las unas, porque alguno de los regímenes autoritarios de Occidente, en cuyo seno proliferó el fenómeno turístico, desarrolló una Política Social que contaba con dichos movimientos y los aprovechaba para elogiar, usando la propaganda, el buen balance del sistema. Migraciones que asimismo nacieron de los beneficios que la Política Social del Estado social y democrático de Derecho introdujo para liquidar situaciones de mala conciencia y saldar las deudas pendientes del Estado demoliberal. No dejó de influir el ambiente de transformación económica que, antes de agotarse las reservas extractivas de los países descolonizados, creaba condiciones propicias a esta variante de progreso social y a la eficacia lucrativa de las migraciones turísticas. Así se enriqueció el contenido esencial o núcleo invulnerable del derecho de propiedad de corte clásico - remozando el conjunto de sus facultades- y se vistieron los inte- 
reses desnudos que acampaban fuera del ordenamiento jurídico. Se pretendía que, cumpliendo las funciones sociales de la propiedad privada, la nueva estructura de los patrimonios personales acogiese los derechos subjetivos y las situaciones jurídicas propugnadas por demandas sociales exigentes y comprometidas.

Las causas y la fisonomía del flujo migratorio hacia las zonas litorales, provocan reflexiones de fondo que, además de su crédito científico, representan la aportación más estimable para totalizar —analizándola en sentido pluridireccional - la realidad que las absorbe. El fenómeno de su instalación - deformado por la ansiedad con que el urbanismo salvaje prodigó sus explosiones anárquicas allí donde mediaban las condiciones óptimas para integrar, con algún orden, los intereses concurrentes- obedece a las características que siguen.

Se trata de una experiencia de progreso, porque su conmoción muda los estados de cosas que antes eran tales gracias al uso de los mismos bienes o al aprovechamiento más sencillo de las utilidades obtenidas. Se accede a una experiencia positiva, pues el progreso, sin adjetivar, representa un avance, pero no un concepto sintético que prejuzgue lo ventajoso de sus adquisiciones. El escenario cambia merced a una sustitución que acredita cómo los factores de la transformación redundan en beneficio del enriquecimiento personal y social. La situación a que se adviene, resulta irreversible, al compartir los rasgos de la oferta con que el Estado social y democrático de Derecho corrigió los defectos del Estado de Derecho liberal burgués o convirtió en verdaderas algunas de sus falsas promesas. El principio de irregresividad prohíbe cualquier demora o retroceso en las adquisiciones obtenidas, algo que, por hipótesis, propende a la expansión de la creatividad y condena los estancamientos estériles. La novedad que se advierte, no cierra el paso a otros procesos paralelos o afines, sino que, con las ilusiones puestas en su perfección, se condice con ellos. Las mutaciones del fenómeno - que reclama cobertura frente a los atropellos del urbanismo salvaje-generan mejoras de cantidad, pues aumentan el número de sus beneficiarios, e implican mejoras de calidad, porque, a través del consentimiento general, la conciencia común admite que vale la pena no dilapidar las opciones que tiene a su alcance. Su irreversibilidad les atribuye un poder de crecimiento irresistible, porque su proyección hacia delante lo impone, sin otra alternativa. Ello justifica la multiplicación de las medidas de control y de apoyo frente a las extralimitaciones denunciadas. Se está ante situaciones abiertas e impregnadas de generosidad colectiva, porque su comunicabilidad trasluce una audacia sensata que, en vez de entorpecerlos, alienta los avances debidos al advenimiento de las realidades sociales. 
Se explican, según ello, el decoro y la respetabilidad de los bienes jurídicos que, con motivo de la presencia y el arraigo turísticos en las zonas litorales, hacen aparición. Fenómeno que, aunque sujeto a cambios de accidente, es fiel a una constante cuyas variables no debilitan su consistencia ni desvanecen su importancia. Las acciones oficiales han de ponerlo a salvo - empleando esfuerzos privilegiados y compromisos no menos tenaces- de las patologías con que el urbanismo deletéreo amenaza los valores de su normalidad y el atractivo de su porvenir.

La voracidad económica de la agresión urbanística, que estimulan las convergencias migratorias en los espacios litorales, registra episodios caracterizados por el acatamiento resignado de situaciones sin enmienda y por el uso de fórmulas transaccionales que las curan de sus aberraciones. Estos hechos — que, para sonrojo general, han dado buena cuenta del imperio de un ordenamiento jurídico arrinconado por un alud de acontecimientos imparables- se localizan en espacios polémicos que, a causa de la morfología del suelo litoral, comprenden las zonas densas o compactas, las superficies de discontinuidad y los espacios húmedos.

El aliciente de las dos primeras ha excitado la actuación de los derechos básicos que conducen a la instalación en las franjas costeras. La libre circulación de personas encarna el derecho preferentemente ejercitado, tras las adquisiciones del Estado social y democrático de Derecho, y supone una movilidad inseparable del tránsito de bienes y cuantos objetos análogos enriquecen la esencia del derecho central. La libertad de elección de residencia culmina los efectos especiales del arraigo y se sirve de los desplazamientos que la libre circulación autoriza. Intervienen, en fin, el disfrute ordenado del ocio y otras formas de esparcimiento que mejoran la calidad de vida.

Hace, además, acto de presencia una dimensión colectiva, cuyos intereses atañen al aprovechamiento de esos fines y a las particularidades de la organización requerida para disciplinar la situación. La clave reside en el diagnóstico de las exigencias de presente y en el pronóstico de las necesidades innominadas que se atisban. De ahí, la recepción de procesos productivos ya en marcha y que, no por su habitualidad y frecuencia, dejan de añadir interrogantes — de dimensión y de estructura- que exigen soluciones de reconversión industrial y readaptación profesional. Hay ciclos de actividades generadas por la economía de los asentamientos litorales o transferidas de sus lugares de origen a otros en que las dificultades de acomodación se acrecientan. Si, hasta entonces, satisfacían los aspectos renovadores de lo tradicional y conocido, hoy miran a los propios de la curiosidad innovadora. Conforme a 
los dogmas consumistas de la vida económica, la lista de las necesidades preexistentes se enriquece con otras — de factura reciente- que imponen la oferta de bienes y servicios ajustados a la realidad sobrevenida. La economía libre de mercado acoge originales aventuras productivas - fruto de la migración concentrada en los espacios litoralescuyas intuiciones de progreso son, para bien o para mal, tan numerosas como impredecibles.

Lo que, así las cosas, goza de una innegable seducción para actualizar iniciativas precedentes o abordar inéditos proyectos, no se concibe sin la asistencia de unos hábitos racionalizadores. No se trata del paso a la modernidad radical, que encandila con lo espectacular de sus retos, ni de transformar las superficies costeras en espacios geográficos irreconocibles, pese a la frecuencia con que las agresiones urbanísticas forjaron sus éxitos en ellas. Prevalece —con voluntariosa honestidad y ardor publicitario- el propósito de conservar la identidad medioambiental y ecológica de los espacios afectados. En la base de estas actitudes, anida una enconada resistencia - que hace valer la causa de un pasado digno de defensa - a aceptar, sin más, el olvido y la pérdida de los paraísos perdidos. Aun así, cuesta sobremanera conciliar la rudeza de los afanes lucrativos — anejos a los ataques urbanísticos contra la naturalidad de los espacios litorales- con la utopía cuasipastoril de que, al seguir siendo todo igual, las mudanzas acaecidas no disipan su encanto, sino que, gracias a su actualización, lo conservan indemne.

La metodología defensiva de los espacios litorales comprende soluciones de control - protector de sus excelencias-y de depuración, para evitar la perversión física y jurídica de las zonas costeras que, una vez iniciada, excita la agresividad del adversario y reduce la posibilidad de detenerla. No se cuenta con exceso de facilidades a la hora de combatir estos trances de destrucción o deterioro. El tratamiento tutelar pretende que, al precio de su compromiso categórico, el acceso a las zonas litorales se libere de impedimentos físicos que — si comúnmente no entrañan irregularidad alguna, como efecto, que son, del ejercicio normal de otros derechos o de la adopción de medidas legítimas- aquí adquieren una consideración especial. Hay que abrir los espacios destinados a igualar una protección que, sin la asistencia de los esfuerzos de transformación, no tiene visos de llegar muy lejos.

Las zonas territoriales de complementariedad evitan que la identidad e integridad de los espacios litorales sucumban a la amenaza de las injerencias arquitectónicas o de las infracciones de las normas esenciales de urbanización. Hay que imaginar, hasta el hartazgo, soluciones y arbitrios que cuiden de la cosmovisión del atractivo litoral, de la percepción de los 
paisajes, que transmiten placenteras impresiones, y de la templanza de su contemplación. Procede una campaña -inexorable y de vastas dimensiones- contra el ímpetu de los extravíos que envilecen valores estéticos de primera línea y se aprestan a perpetuar su atrocidad. Se vuelve, con evocadora nostalgia, a la concepción de la belleza que - frente al voluntarismo de las versiones dictadas por administradores de ocasión- la define como la cualidad de las personas y las cosas que, vistas y/o sentidas, producen reacciones de satisfacción y deleite.

\section{Defensa de las comunidades asentadas en las zonas costeras}

Ciertas comunidades -enclavadas en los espacios litorales- han alcanzado un nivel de madurez que tampoco escapa a las afrentas del urbanismo salvaje. Sus poblaciones comparten, como toda colectividad que ha superado la sencillez de sus orígenes, la conciencia histórica de sobrevivencia y la conversión de sus necesidades individuales en necesidades colectivas. Convencidos de la consistencia y continuidad de su destino, reflexionan sobre sus consecuencias, ponderan la necesidad de proteger sus intereses y concilian la intervención de las personas con el manejo de los recursos a su alcance.

La comunidad constituye un grupo de individuos que, en el seno de la sociedad pluralista, adivina los estímulos de este modo de vida y asume los riesgos que su prospección insinúa. Las comunidades son titulares de un derecho colectivo a subsistir, a beneficiarse del esfuerzo de sus pobladores — protagonistas de un mal de crecimiento- y al favor del Derecho objetivo que sana sus insuficiencias. Sus intereses legítimos chocan con los excesos urbanísticos que -intencional o negligentemente- les colocan en trance de extinción. Algunas gozan de la cobertura institucional de los órganos de democracia delegada que se ocupan de aquellos intereses. Otras evolucionan espontáneamente, soportan renovaciones sucesivas y no logran forjar una defensa suficiente para reprimir las agresiones. Su protección no es cabal sin los auxilios - típicos o innominados - que, para asegurar el peso específico de las libertades agobiadas, competen a los poderes públicos. Su apoyo completa las acciones de democracia directa que, sin merma de su valor testimonial, decaen si no se complementan con esa suerte de acompañamientos.

El principio que exalta el robustecimiento de las comunidades - asentadas en la corona litoral, y conminadas o heridas de muerte por las amenazas del urbanismo salvaje- pertenece a una máxima de gran cabotaje que concibe el crecimiento accesible como un hito erigido en 
el curso de una sucesión, gradual y edificante, de buenos resultados. Siempre y cuando, además de atender a las dimensiones y equilibrios de los procesos que emergen en la esfera mundializadora, no se resienta la continuidad de otros proyectos, ni se sacrifiquen los bienes presentes y pasados de las comunidades.

\section{Salvaguarda de otras variantes de la riqueza litoral}

Los peligros que nacen del urbanismo agresivo, afectan a otros aspectos necesitados de tutela. La riqueza biológica, sumergida en el mar litoral, obliga - ante lo delicado y vario de sus artes de conservacióna redoblar los modos de protección bastantes para eliminar los peligros que le acechan. Hay que constituir obligaciones de fines, cuya ejecución impida el deterioro temido o iniciado, porque se quedan cortas las obligaciones de medios que - aunque se frustre la satisfacción de los intereses cuestionados - liberan, en detrimento del acreedor o acreedores, al deudor que acredite - lo que no es excesivamente fatigosohaber usado de la diligencia que cabe exigirle. Recurrir a obligaciones de esta traza es desdeñar la importancia del derecho amparado y usar del cinismo jurídico más espeso para dejar fuera de juego la protección de unos bienes que, so pena de irremediable deterioro, hay que tutelar en forma específica.

Resulta ineludible preservar la plataforma continental frente a las agresiones indicadas. Este talud o superficie descendente aloja valiosos yacimientos que requieren un tratamiento adecuado a la escasez y notabilidad de su riqueza. Todo episodio de urbanización en los espacios litorales queda condicionado, en su caso, por la existencia de una plataforma continental que abunda en recursos privativos de su situación y oportunidades productivas. Es natural implantar un régimen de limitaciones para suprimir el más menudo de los riesgos que afectan a una parcela tan valiosa de la riqueza nacional. Además de ocuparse de la conservación actual de estos bienes, las competencias oficiales han de acudir a dos clases de acciones. Las unas aplican medios de inmunidad óptima que aseguran el futuro de la plataforma continental. Las otras —de utilización periódica e ineludible- comprueban la suficiencia de las medidas puestas en práctica y vigilan la evolución que requiere modernizar esos recintos. No sólo la imposición de sanciones, sino también un clausulado que detalle las hipótesis de responsabilidad por los daños que causan las agresiones urbanísticas, pueden equilibrar el ejercicio de los derechos concurrentes y evitar las disfunciones que, de lo contrario, van a darse. 


\section{Funciones sociales de la propiedad privada en los espacios litorales}

La propiedad privada constituye un derecho individual que se disfruta en régimen de colimitación, pues sus titulares se prevalen de las restricciones impuestas a la actuación de otros derechos y, en la medida de cada circunstancia, acatan las moderaciones que exige su supervivencia.

La propiedad privada - al igual que la posesión de las cosas y derechos- realiza las funciones sociales que el Estado social y democrático de Derecho puso en vanguardia de las renovaciones ideadas para - ajustando cuentas - saldar deudas pendientes del Estado demoliberal y asignar a los particulares el papel que les correspondía en punto a los servicios esenciales de la comunidad. El olvido intencional de sus funciones sociales desautoriza el éxito del derecho de propiedad privada y evidencia su derrota frente a otros derechos, cuya agresividad está en razón inversa de la juricidad que les falta. Se abusa positivamente del derecho de propiedad cuando sus facultades operan en demérito de sus fines, y negativamente si, llegado el tiempo de actuar sus funciones sociales, se omiten voluntariamente las cargas que las constituyen.

Semejante función social gana importancia en los espacios litorales, donde las variantes del derecho de propiedad se han manejado con irresponsabilidad y ligereza. Los propietarios del suelo -integrantes de las comunidades cuya supervivencia se protege- han cedido a las seducciones especulativas que, a cambio de un enriquecimiento inesperado y fácil, destruyen las formas de vida que, como sanas y óptimas, se habían aceptado y aquirido. El fracaso de la función social puede deberse a la avidez — tan inmadura como sorprendida - de los propietarios, prestos a obtener un lucro que atrapa su codicia, o a la cautividad de las formas de atracción que, salvo excepciones, enervan la capacidad de resistir en nombre de valores dignos de conservación. La aceleración de este proceso forma parte de la actitud frenética con que los hábitos del urbanismo salvaje prostituyen la vida de los espacios litorales.

El fenómeno de salida y puesta en el mercado de los bienes de esas instalaciones urbanísticas, se acompaña de prácticas publicitarias que -usando de una literatura equívoca y tenaz - anuncian el propósito de respetar las funciones sociales de la propiedad privada, siendo así que se proponen todo lo contrario. Cuando, en contadas ocasiones, las ofertas adquieren un tono mesurado que las hace fiables, se compromete el futuro de las responsabilidades que pueden surgir, si se defraudan las que entonces resultan ser promesas rotas. 
Las funciones sociales se infringen si las acciones urbanísticas perturban, en los espacios litorales, las normas de apertura y disciplina de la competencia. Cierto que el contenido esencial o núcleo invulnerable del derecho de propiedad privada incluye - a fin de compensar los riesgos de su titularidad y ejercicio - la facultad de graduar determinados usos. Aquí se censura la antisocialidad consistente en restringir o hacer herméticas las parcelas del mercado urbanístico, sin justificación objetiva y razonable de una diferencia de trato que afecta a las demandas de los bienes que los fenómenos urbanísticos ofrecen. El principio de libertad de contratación no soporta la irrazonabilidad de condiciones generales que, sin perjuicio de aquella discriminación, atentan contra la autonomía de la voluntad en los negocios jurídicos.

\section{Conclusión}

Las reflexiones hechas pretenden subrayar cómo la flexibilidad de un Derecho de principios sirve al rigor de un Derecho de preceptos que, ante la irrupción del urbanismo salvaje en los espacios litorales, acusa infracciones sensibles y abundantes, y, lo que es más de lamentar, no siempre ha contado con la contribución - perseverante, incondicional y solidaria - de los agentes sociales obligados a defender los bienes jurídicos agredidos. 